\title{
Bookshelf 2017
}

\author{
Richard Price and Sally Price \\ Anse Chaudière, 97217 Anses d' Arlet, Martinique \\ rixsal@gmail.com
}

Once again, in order to provide a window on the current state of Caribbean book publishing for NWIG readers and contributors (as well as the authors of books reviewed in the journal), we offer a brief analysis, based on seven of the journal's most recent issues (volume $89-3 \& 4$ [2015] through volume 92-3\&4 [2018, not yet published]). Note that because we aim at providing full reviews of more than 5 o nonfiction books per issue, this rundown does not include many other books that were published during the relevant period.

During this three-and-a-half-year run of issues, we published (or will publish) full reviews of 373 books from 97 publishers. Thirteen publishers provided nine or more titles, accounting for $5^{2}$ percent of the total, with Palgrave Macmillan contributing the most (27 titles). The others were University Press of Florida (24), University of North Carolina Press (24), University of the West Indies Press (21), Duke University Press (17), University of Virginia Press (15), Routledge (12), Oxford University Press (11), Liverpool University Press (10), Lexington Books (10), Ian Randle (9), University of Mississippi Press (9), and Yale University Press (9). Another 13 publishers contributed 4-8 books each, accounting for 21 percent of books reviewed. The remaining 71 publishers provided 1-3 titles -27 percent of the books reviewed.

If we consider the contents of our annual Bookshelf round-up (which, unlike the reviews, includes fiction and poetry), the number of publishers more than doubles (as does the number of books). The Bookshelf essays in our sample have discussed or listed 564 titles from an additional 229 publishers, which brings the total number of publishers we've been dealing with during the period to 326 .

Caribbean publishing, then, is widely dispersed, representing a specialty for only a handful of editorial houses. The majority of books on the region are provided by publishers that bring out only one or two relevant titles annually.

In terms of disciplines covered in the full reviews, history dominated (about 45 percent), with literature, including a consistently strong Francophone component, in second place at 18 percent. Anthropology and cultural studies fol-

(C) RICHARD PRICE AND SALLY PRICE, 2018 | DOI: 10.1163/22134360-09201053

This is an open access article distributed under the terms of the prevailing CC-BY-NC license 
lowed closely (some 17 percent of reviews), with politics, music/art/dance, archaeology, and linguistics completing the list.

In terms of regions, 33 percent of reviews were devoted to books that considered the Caribbean or the Atlantic World as a whole, and 14 percent dealt with the Anglophone Caribbean as a whole. Books about Cuba dominated the single-country list (about 17 percent of books reviewed), followed by Haiti (10 percent), Jamaica (7 percent), and Puerto Rico (6 percent). Books about other Caribbean places (the Dominican Republic, the Lesser Antilles, Suriname, et cetera) made up the additional 13 percent.

This year, once again, we express our gratitude to all the reviewers who have, collectively, provided such a rich resource for keeping up with writing on the region. At the same time, we must lament the fact that some of the people who've accepted a book and promised to review it have, despite a long series of gentle reminders over a year or two, never shared their reactions to the book with NWIG readers. With our apologies to the authors of books that have therefore not been given their due in these pages, we simply list them here16 books that we had intended to review, but for which the reviewers were negligent:

Atlantic Africa and the Spanish Caribbean, 1570-1640, by David Wheat (Chapel Hill: University of North Carolina Press, 2016, cloth US $\$ 45.00$ )

I and I: Epitaphs for the Self in the Work of V.S. Naipaul, Kamau Brathwaite and Derek Walcott, by Rhonda Cobham-Sander (Kingston: University of the West Indies Press, 2016, paper US\$38.0o)

Antiracism in Cuba: The Unfinished Revolution, by Devyn Spence Benson (Chapel Hill: University of North Carolina Press, 2016, paper US\$29.95)

A New Chapter in US-Cuba Relations: Social, Political, and Economic Implications, edited by Eric Hershberg \& William M. LeoGrande (Basingstoke, U.K.: Palgrave Macmillan, 2016, cloth US\$105.00)

Revolution within the Revolution: Women and Gender Politics in Cuba, 1952-1962, by Michelle Chase (Chapel Hill: University of North Carolina Press, 2016, paper US\$29.95)

Globalization, Sovereignty and Citizenship in the Caribbean, edited by Hilbourne A. Watson (Kingston: University of the West Indies Press, 2015, paper US\$40.00)

Chasing Religion in the Caribbean: Ethnographic Journeys from Antigua to Trinidad, by Peter Marina (Basingstoke, U.K.: Palgrave Macmillan, 2016, cloth US\$99.99)

Humanitarian Aftershocks in Haiti, by Mark Schuller (New Brunswick NJ: Rutgers University Press, 2016, paper US\$27.95)

Dangerous Neighbors:Making the Haitian Revolution in Early America, by James Alexander Dun (Philadelphia: University of Pennsylvania Press, 2016, cloth US\$45.00) 
Troubling Freedom: Antigua and the Aftermath of British Emancipation, by Natasha Lightfoot (Durham NC: Duke University Press, 2015, paper US\$25.95)

Tell My Mother I Gone to Cuba: Stories of Early Twentieth-Century Migration from Barbados, by Sharon Milagro Marshall (Kingston: University of the West Indies Press, 2016, paper US\$30.0o)

The Borders of Dominicanidad: Race, Nation, and Archives of Contradiction, by Lorgia García-Peña (Durham NC: Duke University Press, 2016, paper US\$24.95)

The Dominican Racial Imaginary: Surveying the Landscape of Race and Nation in Hispaniola, by Milagros Ricourt (New Brunswick NJ: Rutgers University Press, 2016, paper US\$27.95)

The Dutch Moment: War, Trade, and Settlement in the Seventeenth-Century Atlantic World, by Wim Klooster (Ithaca NY: Cornell University Press, 2016, cloth US\$35.0o) Cast in Deathless Bronze: Andrew Rowan, the Spanish-American War, and the Origins of American Empire, by Donald Tunnicliff Rice (Morgantown: West Virginia University Press, 2016, paper US\$27.99)

Black Autonomy: Race, Gender, and Afro-Nicaraguan Activism, by Jennifer Goett (Stanford CA: Stanford University Press, 2016, paper US\$25.95)

Some of the books that we requested from publishers, often multiple times, never reached us (for Bookshelf) or the person who had agreed to provide a full review:

Carlos Luna, by D. Barbaro Martinez-Ruiz, Henry Drewal, Carol Damian \& Jack Rasmussen (Milan: 5 Continents Editions, 2017, cloth US\$80.00)

John Dunkley: Neither Day nor Night, by Diana Nawi (Munich, Germany: Prestel, 2017, cloth US\$45.00)

Frank Walter: The Last Universal Man, 1926-2009, by Frank Walter (Santa Fe NM: Radius Books, 2017, cloth US\$55.00)

The Legacy of Eric Williams: Into the Postcolonial Moment, edited by Tanya L. Shields (Jackson: University Press of Mississippi, 2015, cloth US\$6o.oo)

Cuba: This Moment, Exactly So, by Lorne Resnick(New York: Insight Editions, 2017, cloth US\$29.99)

Peacekeeping, by Mischa Berlinski (New York: Atlantic, 2016, paper US\$18.0o)

Ni noires ni blanches: Histoire des musiques créoles, by Bertrand Dicale (Paris: Philharmonie de Paris, 2017, paper $€ 13.90)$

Slavery and Abolition in the Atlantic Cannabis Lifestyle, with 75 Herb-Boosted Recipes, by Cedella Marley with Raquel Pelzel (New York: Pam Krauss/Avery, 2017, cloth US\$30.00)

Wicked Weeds: A Zombie Novel, by Pedro Cabiya (Simsbury CT: Mandel Vilar Press, 2016, paper US\$16.95) 
Slavery and Abolition in the Atlantic World: New Sources and New Findings, edited by Jane Landers (London: Routledge, 2017, cloth US\$149.95)

Archipelagic American Studies, edited by Brian Russell Roberts \& Michelle Ann Stephens (Durham NC: Duke University Press, 2017, paper US\$30.95)

Since We Fell, by Dennis Lehane (New York: Harper Collins, 2017, cloth US\$27.99)

The Dictator, by David Layton (Toronto: HarperCollins Canada/Patrick Crean Editions, paper US\$22.99)

Domingo de revolución, by Wendy Guerra (Barcelona: Anagrama, 2017, paper €16.90)

Cuba, by Elliott Erwitt (Kempen, Germany: teNeues, 2017, cloth US\$ 75.00) [129 duotone photos; text in English, German, and French]

Marley Coffee Cookbook: One Love, Many Coffees, and 100 Recipes, by Rohan Marley \& Maxcel Hardy III, with Rosemary Black (Beverly MA: Quarry Books, 2017, cloth US\$25.00)

Leviticus, by Kamau Brathwaite (St. Martin: House of Nehesi, 2017, paper US\$25.00), described by the author as "The first poem of the Burning of the Body/and the Tearing of the Flesh," written in Sycorax Video style. [This book may have been another victim of the hurricanes]

The Tryst, by Monique Roffey (s.l., U.K.: Dodo Ink, 2017, £8.oo)

A Taste of Cuba: Exploring the Island's Unique Places, People, and Cuisine, by Liza Gershman (New York: Skyhorse Publishing, 2017, cloth US\$29.99)

Comida Cubana: A Cuban Culinary Journey, by Marcella Kriebel (Minneapolis MN: Burgess Lea Press, 2017, Cloth US\$30.0o)

Paladares: Recipes Inspired by the Private Restaurants of Cuba, by Anya von Bremzen \& Megan Fawn Schlow (New York: Abrams, 2017, cloth US\$40.oo)

Cines de Cuba, by Carolina Sandretto (photographer) (New York: Skira, 2017, cloth US\$75.00)

Bone, by Yrsa Daley-Ward (New York: Penguin, 2017, paper US\$15.00)

Cuba on the Verge: 13 Writers on Continuity and Change in Havana and Across the Country, edited by Leila Guerriero (New York: Ecco, 2017, cloth US\$26.99)

N.B. Caraïbéditions, based in Lamentin, Martinique, is the only publisher we know that replies to our requests for review copies with the statement that, as a matter of principle, they never send review copies. We were therefore unable to review the two books of theirs that we requested this year: L'insurrection de l'âme: Frantz Fanon, vie et mort du guerrier-silex, by Raphaël Confiant (2017, paper n.p.) and Le miroir d'Annabelle, by Lyonel Trouillot (2016, paper n.p.).

Trying to find out about Caribbean books to review from more than 300 publishers will always be hit-or-miss. We've become aware of several books from the past three years that should have been reviewed, but that we (inadvertently and unfortunately) missed: 
Everyday Moral Economies: Food, Politics and Scale in Cuba, by Maria Wilson (Oxford: Wiley-Blackwell, 2014, paper £24.99)

Contrary Destinies: A Century of America's Occupation, Deoccupation, and Reoccupation of Haiti, by Leon D. Pamphile (Gainesville: University of Florida Press, 2015 paper US\$19.95)

Cuba, the United States, and Cultures of the Transnational Left, 1930-1975, by John A. Gronbeck-Tedesco (Cambridge: Cambridge University Press, 2015, paper US\$31.99)

Thiefing a Chance: Factory Work, Illicit Labor, and Neoliberal Subjectivities in Trinidad, by Rebecca Prentice (Boulder: University Press of Colorado, 2015, paper US\$34.95)

Remixing Reggaeton:The Cultural Politics of Race in Puerto Rico, by Petra Rivera-Rideau (Durham NC: Duke University Press, 2015, paper US\$23.95)

Interplay of Cultural Narratives in Martinique: French, African, and Indian Journeys toward a Pluralistic Society, by Mahadevi Ramakrishnan \& R. Scott Smith (Pompano Beach FL: Caribbean Studies Press, 2015, paper US\$24.50)

Ideology, Politics, and Radicalism of the Afro-Caribbean, by Jerome Teelucksingh (New York: Palgrave Macmillan, 2016, US\$99.99)

America's Forgotten Colony: Cuba's Isle of Pines, by Michael E. Neagle (Cambridge University Press, 2016, paper US\$29.99)

A Year in White: Cultural Newcomers to Lukumi and Santería in the United States, by C. Lynn Carr (New Brunswick NJ: Rutgers University Press, 2016, paper US\$27.95)

Finally, one for which our reviewer became too ill to complete: Negotiating Gender, Policy and Politics in the Caribbean: Feminist Strategies, Masculinist Resistance and Transformational Possibilities, edited by Gabrielle Hosein \& Jane Parpart (London: Rowman \& Littlefield International, 2016, paper US\$45.95)

We apologize to all these authors for not being able to review their books.

This year's Bookshelf begins with a rich crop of fiction.

Mind-bending, ever-flowing Heretics (New York: Farrar, Straus and Giroux, 2017, cloth US\$28.0o), by Leonard Padura (translated by Anna Kushner), begins in the contemporary Havana of his by-now-famous private eye (and secondhand book dealer) Mario Conde and his close friends (all as macho as he is), where a long and elaborate mystery regarding a missing painting and a Jewish family unfolds itself back into the 1930s, then moves on to seventeenthcentury Amsterdam (the New Jerusalem), where Rembrandt and his Sephardic associates (described in fine detail) are in full mettle, and ultimately ends back in dreary, gritty contemporary Cuba. In this sprawling work, Padurawho has won countless literary prizes in various countries-continues his political high-wire act as Cuba's most popular living author, toying with the limits of what can be said. In the end, Heretics strikes us as a kind of Cuban The 
Recognitions, William Gaddis's great novel about art, and we rate it the most interesting of this year's novels.

Prize-winning poet and novelist Kei Miller's Augustown (New York: Pantheon, 2017, cloth US\$24.95) weaves together Jamaican vernacular storytelling about the turn of the century (versions of Alexander Bedward as the "flying preacher") and the more recent past (class, color, sexism, violence) into a sometimes horrifying, often lyrical, and always gripping narrative. Highly recommended. (The French translation won the 2017 Prix Carbet de la Caraïbe et du Tout-Monde.)

Touted as the literary event of the year: the publication of Jamaica-born Claude McKay's long-lost (and never before published) final novel, Amiable with Big Teeth: A Novel of the Love Affair between the Communists and the Poor Black Sheep of Harlem (New York: Penguin, 2017, paper US\$17.00), edited with an unusually informative introduction by Jean-Christophe Cloutier \& Brent Hayes Edwards. Set in 1936, the story features a slew of characters, many identifiable, engaged in the black nationalist vs. international Communist struggle brought on by Mussolini's invasion of Ethiopia. At once pointedly satirical and, at least at times, affectionate, the novel depicts a range of mostly "Aframerican" actors (false professors, fake Ethiopian princes and princesses, Harlem socialites ...) navigating the parade-filled streets, the churches and lodges, the jazz-filled dives, and the sitting rooms of a Harlem bent on solidarity with Haile Selassie. Engaging, funny, and sad-and written from a distanced perspective, appropriate for an immigrant like McKay-it's a fitting tribute to one of the greats of the Harlem Renaissance.

In Moving Forward Sideways like a Crab, by Shani Mootoo (Brooklyn NY: Akashic, 2017, paper US\$15.95), the narrator, brought up in Canada by his East Indian Trini birth mother and her female lover, discovers the latter many years later, now transitioned into a man, living in Trinidad. Slow twists and turns in the characters' lives, including a mysterious murder, play out against vivid descriptions of the landscape and social world of Trinidad. A strong story of sexual identities, and love.

In Curfew Chronicles: A Fiction (Leeds, U.K.: Peepal Tree, 2017, paper £ 9.99), poet and short story writer Jennifer Rahim recounts, with pathos, humor, and an exceptional gift for words, a day in Trinidad during the 2011 State of Emergency imposed by the government in response to a rise in criminal activity. The 31 mini-stories weave in and out of the lives of a lawyer-lady, a hired gunman, a Pentecostal convert, a Woodford Square soapbox lecturer named Scholar (in the venerable tradition of Man-Man in Naipaul's Miguel Street), and dozens of others. Having read an advance copy from the publisher, we're waiting for news of the literary prizes it amply deserves. 
Even in Paradise (Brooklyn NY: Akashic, 2016, paper US\$15.95), Elizabeth Nunez's tenth novel, displaces a King Lear plot to the Caribbean, roaming between Trinidad, Jamaica, and Barbados, as three well-off white Trini sisters grapple with each other over their father's inheritance and their choice of husbands. Race, family, and identity join jealousy, greed, and betrayal in this engaging tale, narrated by a young bourgeois, literary-minded black Trinidadian who ends up with the finest of the girls.

The Last Ship (Leeds, U.K.: Peepal Tree, 2015, paper £8.99), by Jan Lowe Shinbourne, traces without sentimentality the stark, poverty-stricken lives of late-nineteenth-century Chinese immigrants to British Guiana through three generations, emphasizing their social ties with plantation (East) Indians, the realities of class and ethnic inequality, and Chinese ethnic chauvinism under colonialism.

In her debut novel, Fingerprints of Previous Owners (Los Angeles: Unnamed Press, 2017, paper US\$16.0o), Rebecca Entel takes on the challenge of writing as a white American in the voices of Bahamian out-islanders. While her storytelling gifts are apparent, we find the narrative voices a bit off-key, making for a mixed performance. Well-meaning, this story told through the eyes of locals who work at an American resort doesn't quite fit the lived experience of Caribbean folks we've known who work at hotels. Too many stereotypes, too few insider insights. But you be the judge.

In Fried White Grunts (Abbeville SC: Moonshine Cove Publishing, 2017, paper US\$13.99), F. Colin Duerden reminisces about his boyhood in pretelevision rural Bermuda, recounting, as if to a ten-year-old boy, playing cowboys and Indians (learned from U.S. comic books and films), flying kites, and monkeyshines involving peeing and other experiments with the willy. Hardly great literature but it introduces various island realities, far from the tourist circuit.

In his second novel, The Stall Keeper (Vieux-Fort, St-Lucia: Jako Books, 2017, paper US\$24.99), Anderson Reynolds offers a coming-of-age story set in 196os Vieux-Fort, filled with strong characters-Seventh-Day-Adventists ("Semdays"), cricketers, American GIs, fishermen, and a man doing women's work selling fruit in a roadside stall. The strong very local color somewhat makes up for the prosaic writing.

Grounds for Tenure (Kingston: University of the West Indies Press, 2017, paper US\$35.0o) is retired UWI language-and-literature professor Barbara Lalla's fourth novel, this one set in Jamaica. Beginning at a slow pace, its plot speeds up, reaching a rich climax of corruption, pretense, and tomfoolery in a recently established university. The book dwells on many of the foibles of modern academia and its denizens, from padded CVs to online pay-for-play 
PhD dissertations, whether in the United States, England, or the Caribbean. A classic academic novel with West Indian flavors.

In Sugar Money (London: Faber \& Faber, 2017, cloth US\$24.99), British historical novelist Jane Harris turns to the Caribbean for the first time, basing her tale on a true eighteenth-century event. Her protagonist, a young teenage boy born into slavery on Grenada, is now enslaved in Martinique and, along with his older brother, is charged with going back to his birthplace to "steal" 42 slaves, once the property of French friars, now in British hands, and transport them back to Martinique. This is an adventure story of the sort a teenager might enjoy. We're less sure it will appeal to readers of NWIG.

In The Art of Death: Writing the Final Story (Minneapolis MN: Greywolf, 2017, paper US\$14.00), Edwige Danticat moves quickly outward from dealing with her mother's battle against cancer to other writers' encounters with death. Danticat is direct, moving, and wonderous in commenting on a range of diverse literature. A beautiful little book.

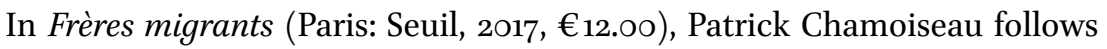
an imagined call from his late friend Édouard Glissant to write about the "barbary of borders and the crimes that they cause." In highly poetic (and often pretentious) prose, the Martiniquan novelist rails against neoliberalism, inequality, and violence, touting instead liberty, equality, fraternity, sharing, diversity, and human dignity. A soaring hymn to Glissant's ideal of "la Relation," with some choice jibes at "the man under a blond forelock who commands the world's most powerful nation." Little new here but perhaps uplifting, if you like that sort of thing. Yale University Press has an English-language version scheduled for May 2018.

The Restless (New York: The Feminist Press at CUNY, 2018, paper US\$16.95) is Judith G. Miller's translation of Les rétifs (2012), the debut novel by Guadeloupean poet and playwright Gerty Dambury, followed by a conversation between translator and author. The main character is nine in 1967 Pointe-à-Pitre (Dambury was ten), when labor strikes produced harsh, murderous reprisals from the French state, killing nearly one hundred unarmed citizens. Stressing the ambiguous political status of postdepartmentalization Guadeloupe (French but not really French) and the persistence of class and color inequalities, the novel focuses on a single family's imbrication in these bloody events. The coverup and silencing of this massacre by the State shows strong continuities between then and now. Explicitly structured like a quadrille (an Antillean dance somewhat like an American square dance) the novel includes dialogues between the living and the dead as well as other creole realities.

Marijosé Alie, prominent Martiniquan singer, French Tv hostess, and recently-retired French TV executive, writes that she has decided to devote herself 
henceforth to writing and music. Her debut novel, Le convoi (Paris: Pocket, 2017, paper $€_{7.80}$ ), combines the exoticism of its setting in Guyane (overflowing into Suriname and Brazil) and its many Amerindian characters with a Story of $O$-style sexuality, featuring dozens of (mostly European) adventure-seeking female tourists. A very French gaze on this ancient colony, expressed in lush but somehow cheap prose. (Recently, she told us that our own writings inspired this book, but we can't quite imagine how.) The cover says it won last year's Prix Ivoire for African Francophone Literature.

We celebrate the republication of The Violins of Saint-Jacques, by Patrick Leigh Fermor (New York: NYRB Classics, 2017, paper US\$14.00), a period piece and Fermor's only work of fiction, originally published in 1953. The novella about what he calls "creole" (béké) society on the eve of the 1902 eruption of Martinique's Mont Pelée remains an elegant read, a chronicle of whitefolks' excesses during a final carnival.

L'étoile Absinthe (Paris: Zulma, 2017, $€_{17.50}$ ) is a previously unpublished, unfinished work by the great Haitian novelist Jacques-Stephen Alexis, featuring Églantine (known as la Niña Estrellita, a young Cuban-born prostitute, in his L'espace d'un cillement [1959]), who now begins a new life as a businesswoman and, for most of this text, flowing with evocative words, experiences the effects of a great hurricane aboard a small sailing ship off Haiti's coast. Murdered by Papa Doc's thugs, this writer now speaks from the grave in a torrent of wondrous language.

Belle merveille (Paris: Zulma, 2017, paper $€ 16.50$ ) is poet James Noël's debut novel, bursting with poetic interior monologues against the backdrop of postgoudougoudou Haiti. Zulma has also just brought out a new edition of Le Goût des jeunes filles, by Dany Laferrière (2017, paper € 9.95), first published in 1992 and since republished several times as well as having inspired a film written by the author.

A classic of Haitian literature, Dance on the Volcano, by Marie Vieux-Chauvet (Brooklyn NY: Archipelago, 2017, paper US\$18.oo), originally published in French in 1957, has been expertly translated by Kaiama L. Glover. In this periodpiece novel about Haitian society on the cusp of the Revolution, Vieux-Chauvet depicts the complicated relations between gens de couleur libres and enslaved Africans as well as the whole color/class system (even including maroons), from the perspective of a young, exceptional free woman of color. It's great to have it in English.

René Depestre's Hadriana in all my Dreams (Brooklyn NY: Akashic, 2017, paper US\$15.95), the 1988 winner of the Prix Renaudot and a classic of Haitian literature, has finally been translated into English, masterfully, by Kaiama l. Glover. Written in what the author calls "everyday surrealism," this erotic, magi- 
cal tale of zombies and all-too-real Haitians, set during the 1938 Jacmel carnival remembered from the author's youth, enchants and evokes-Carpentier's real maravilloso in its original setting.

We also note a reprint edition of Jacques Roumain's classic Masters of the Dew (Pompano Beach FL: Caribbean Studies Press, 2017, paper US\$17.00), in the 1947 translation by Langston Hughes \& Mercer Cook, and with an introduction by J. Michael Dash (who has updated the introduction he wrote for the 1977 Heinemann edition and added a section on the spatial politics of the novel).

Mouths Don't Speak (Brooklyn NY: Akashic, 2018, paper US\$15.95), by Katia D. Ulysse, whose 2014 short story collection, Drifting, garnered warm praise from Edwige Danticat and others (and see Bookshelf 2014), opens with stunning images of the Haitian earthquake as experienced via television by Jacqueline, a young Haiti-born woman living in Baltimore. The rest of the novel centers on her complex relationships with her parents (especially her difficult mother), husband (an ex-Marine with PTSD), close friend (an American who helps her relearn Creole), and three-year-old daughter, who dies in a tragic accident in her parents' palatial home in Port-au-Prince.

On m'appelle Nina (Paris: Présence africaine, 2017, paper $€ 19.00$ ) is an autofiction by Jamaica-born Antoinette Tijani Alou who, while studying in Paris, falls in love and follows her husband to his homeland in Niger, discovering the world of the Sahel. Writing as an outsider-insider, she describes what she sees as the wonders of this little-known land.

Papillote Press (London, U.K. and Trafalgar, Dominica) has been publishing, among other excellent books, new editions of some wonderful Caribbean works of fiction, most recently Trinidadian Lawrence Scott's epic and magnificent Witchbroom (2017 [orig. 1992], paper US\$13.00) and Dominican Phyllis Shand Allfrey's classic The Orchid House (2016 [orig. 1954], paper £ 8.99). See also Scott's Leaving by Plane Swimming Back Underwater (2015, paper US\$13.00), a new collection of short stories, published with an accolade from Derek Walcott.

It Happened at Marienburg, Suriname (Paramaribo: VACO, 2017, SRD 118.80), by best-selling Suriname writer Cynthia Mc Leod, is the translation of her historical novel Herinneringen aan Mariënburg (1998), based loosely on the 1902 massacre of East Indian and Javanese sugar workers at the eponymous plantation/factory.

On to short story collections, beginning with five paperbacks from Peepal Tree (Leeds, U.K.):

The Whale House and Other Stories (2015, £8.99), by prize-winning Trinidadian Sharon Millar, collects tales that span the island's class and ethnic divides, 
bringing home the everydayness of violence as well as a variety of domestic concerns. Edgy stories that ring true, written with a controlled intensity.

If I Had the Wings: Short Stories (2017, £9.99), by self-described queer GreekBahamian Helen Klonaris, grapples with the dilemma of growing up under colonialism, homophobia, sexism, and the weight of the Orthodox Church. Vivid and persuasive characters, eroticism, and lush writing, whether the narrator is a male homosexual or, more usually, a growing-up girl dealing with her father's domination.

In The Ten Days Executive: Short Stories (2015, £8.99), Rhoda Bharath captures modern Trinidad with a biting, sardonic, and often deeply comic tone. Memorable vernacular language, the absurdity of characters' pretensions, the gap between social conventions and street life, this book makes reading fun.

The Trinidad-London stories in Come Let Us Sing Anyway and Other Stories, by Leone Ross (2017, paper £9.99), whose back jacket says "may tickle, arouse, and sometimes shock," left us rather cold.

In 2007, Elizabeth Walcott-Hackshaw, professor of French literature at UWI in Trinidad, published her first book of fiction, Four Taxis Facing North, now happily reissued (2017, paper £ 9.99) with an introduction by Lawrence Scottshort stories evoking the inequalities, anarchy, kidnappings, and ways of coping in twenty-first-century T\&T.

The Haunted Tropics: Caribbean Ghost Stories, edited by Martin Munro (Kingston: University of the West Indies Press, 2016, paper US\$20.00), gathers 15 short stories he commissioned from writers across the region-old masters like Maryse Condé, Earl Lovelace, and Madison Smartt Bell as well as younger artists. As varied as the islands they depict, the stories are a pleasure to read and support Munro's claims in the introduction that "Caribbean fiction in general is a collection of ghost stories, tales of haunted people, memories and places." Good fun!

In Trauma: A Collection of Short Stories (Brunswick ME: Shantiarts, 2017, paper US\$17.95), Queens-born Elizabeth Jaikaran, daughter of immigrants from Guyana, presents what she calls "creative non-fiction" in which "the characters are based on real people and the stories are true." Drawing on memories of her own Indo-Guyanese (and Chinese and black) family members, mainly women, she imagines in these first-person narratives the various forms of oppression they experienced. Her characters are often racially and culturally "mixed": "I knew many chapters of the Qur'an by heart. I could speak the new English of my generation and still understand the Hindi of the old generation." Narrators range from gay Hindu women to Amerindians living in the bush and we learn that Guyana has the highest rate of (female) suicide in the world. The book hovers somewhere between social science and imaginative literature. 
In The Tower of the Antilles (Brooklyn NY: Akashic, 2017, cloth US\$19.95), Achy Obejas, equally at home in Spanish and English (she translates professionally back and forth), presents ten Cuba-linked stories, half previously published in literary magazines. Bitter-sweet, often erotic and lesbian-themed, sometimes emotionally difficult to read, most of the stories center on the high costs of staying on the island and the equally high costs of leaving, though some are simpler tales of wonders, like that about a Havana "Superman's" incredibly lengthy dick in the years before the Revolution.

Trinidad Noir: The Classics, edited by Earl Lovelace \& Robert Antoni (Brooklyn NY: Akashic, 2017, paper US\$15.95), differs from other collections in Akashic's "noir" series in that the short stories are reprints rather than originals. But what delicious ones they are, including contributions by C.L.R. James, Sam Selvon, V.S. Naipaul, Michael Anthony, and Derek Walcott, as well as Lovelace, Antoni, and a host of others.

Caribbean poetry has had a busy year.

The Complete Poetry of Aimé Césaire: Bilingual Edition, edited and translated by A. James Arnold \& Clayton Eshleman (Middletown CT: Wesleyan University Press, 2017, cloth US\$50.00), is a true 962-page treasure. The French texts are those published in the remarkable complete edition edited by Arnold in 2013 (see "Bookshelf 2013"). The translations, by the editors (who have been working on Césaire translations for decades), are made from the original editions, as established in that French publication. In the current edition, Arnold provides detailed notes covering variants, historical and cultural references, and the political contexts of publication as well as an illuminating introduction, a chronology, and a glossary. For anyone interested in modern French poetry or in Césaire himself, this book is a must.

Antigua-born classicist N. Gregson Davis presents his own translation of Césaire's Cahier d'un retour au pays natal as Journal of a Homecoming (Durham NC: Duke University Press, 2017, paper US $\$ 22.95)$. We leave the task of comparing the Arnold/Eshleman and Davis translations to the experts but note that, aside from the new translation, this work consists of a somewhat expanded reprint of a 1994 Nigerian publication by F. Abiola Irele, including his notes, introduction, and commentary, as well as the 1956 Présence Africaine text of the Cahier. Davis's translation adds a delicate Anglophone Caribbean touch: he renders Césaire's emblematic "au bout du petit matin" as the Walcottian "At the close of foreday morning" (vs. Arnold/Eshleman's "At the end of the small hours").

In This Breadfruit Kingdom (Kingston: Blouse \& Skirt Books, 2017, paper US\$29.99) is a highly approachable collection of more than 6o short poems chosen by Mervyn Morris, Poet Laureate of Jamaica, as part of his official duties. 
Works by Lorna Goodison, Kwame Dawes, Ishion Hutchinson, Linton Kwesi Johnson, Mutabaruka, and Olive Senior are joined by those of many others. An excellent introduction to Jamaican poetry and a great read.

Peelin Orange: Collected Poems, by Mervyn Morris (London: Carcanet, 2017, US\$13.0o) presents a half-century of poetry in different registers.

Deceptively simple, often thought-provoking, honest and true, Riddim \& Riddles, by Jamaica-born Owen Blakka Ellis (Kingston: Blouse \& Skirt Books, 2014, paper US\$14.95), combines vivid images with thoughts about gender (particularly masculinity), the environment, and history.

In Make Us All Islands: Poems (Bristol, U.K.: Shearsman, 2017, paper US\$17.00), Richard Georges-born in Trinidad and raised in the British Virgin Islands where he lives and works today - delivers a series of lyrical, elegiac poems that uncover an archaeology of the Caribbean archipelago, from Africa and the Middle Passage through slavery to today's domino players, with the sea and its rocks and foam everpresent. We found the language strong and bracing.

To Sweeten Bitter (London: Out-Spoken Press, 2017, paper £ 8.00), by BritishJamaican poet Raymond Antrobus, is a collection of autobiographical verse about relations with his father ("My father had four children / and three sugars in his coffee / and every birthday he bought me / a dictionary which got thicker / and thicker and because his word / is not dead, I carry it like sugar") and about his own identity (British-Jamaican and alternatively white and black). Memory and trying to let go pervade this haunting collection.

Island Bound Mail: Poems (Hemet CA: Kelsay Books, 2017, paper US\$17.00) is the sixth collection by Bermudan-American Nancy Anne Miller, who has also spent time in England. It makes a strong case for Bermuda's inclusion in the Caribbean imaginary: the sea, boats, banana bread, palms and hibiscus, the soft limestone.

ARRIVAL: Poems, by Cheryl Boyce-Taylor (Evanston IL: Northwestern University Press, 2017, paper US $\$ 16.95$ ), casually but beautifully evokes relations with mother, father, children, lover, in Trinidad and New York. Poems of life and death, of red hibiscus flowers and East Indian mangos. "My father had so many women / he stepped between their funk / riding the world ... / a caravan of limbs trailed behind him ... / a small room in his palm reserved for me / his river grew loud and deafening / long wounds on my mother's doorstep." And her mother: "I am the third generation of daughters / whose mother worked as a domestic / in that Great Neck house of poodles and sour cream / girls younger than me / called my mother by a nickname ... / my mother who raised me to call elders / tanty, uncle, granny related or not ... / in that cold New York house / my mother spent three years eating mashed potatoes / and sour cream doing 
sleep-in work / waiting for she green card to come / and every night crying for she beloved daughter / she could not care for while raising the white lady chiren."

In her debut collection, Voodoo Hypothesis (Hamilton ON, Canada: Buckrider Books, 2017, paper US\$18.00), St. Lucia-born Canadian resident Canisia Lubrin offers fiery poems that are at once contemporary and memorializing of Caribbean history, written from both home and the diaspora, many in distant dialogue with Walcott, Césaire, NourbeSe Philip, Ta-Nehisi Coates, and other luminaries, and always combining words unexpected. She truly writes from what she styles "our seabed trail of islands-unbrittle homes ransacked / in cannibal froths of sea."

Six poetry collections in paperback from Peepal Tree (Leeds, U.K.):

In Bajan master poet Kamau Brathwaite's Strange Fruit - "How cultural Lynchin mek the deads re. enter some of our poem(s)"-(2016, £12.99), SVSsycorax video (a kaleidoscope of fonts) reveals straight-from-the-heart verses "written along the v/edge \& coast of death and carrefour $>$ while almost blind \& dumb \& more house-bound pyjamanero every day." Recalling both the Billie Holiday song and the persecution that recently drove him from New York back to CowPastor Barbados, the 87-year-old artist sections his book into "The Lynching Tree," "Friends," "She Poems," "Icons \& Livications" ("Louis Armstrong. Teef of Sorrows" "Orikí fe Madiba" [Mandela]), "Sperrits" ("Ogou(n)"), and "End Poem Poens." There are some memorable visual images as well.

You Have You Father Hard Head (2016, £8.99), by Trini-born Colin Robinson, who has lived most of his life outside the region, presents poems in various genres, most with explicitly gay themes, and often movingly honest.

Collected Poems 1975-2015 (2017, £10.99), by Saint-Lucian John Robert Lee, with an admiring blurb from Derek Walcott, offers an overview of this muchanthologized, very Christian, and very Lucian writer's work. Walcottian cadences, mature, stately, controlled.

Andre Bagoo's Pitch Lake: Poems (2017, £8.99) range from the trees, birds, and beaches of Trinidad to the Texas where Sandra Bland hangs in a cell after not signaling before changing lanes. He's a captivating spinner of tales with a wild imagination.

The poems in Madwoman (2017, £8.99), by Shara McCallum (originally from Jamaica, now living in Pennsylvania), speak to you in a direct elegance. In one called "Race": "You are the original incognito ... / You are so everywhere, so nowhere / ... She's the whitest black girl you ever saw / lighter than 'flesh' in the Crayola box. / But, man, look at that ass and look at her shake it." Madwoman instructs but also questions, both herself and the very personal surrounding world. As she says, "She could sing the never out of gone." 
Mark McWatt's The Language of Eldorado (2017, £8.99), winner of the Guyana Prize for Literature upon its original publication in 1994, has happily been reissued, swirling with images and history of the interior of the country and their myriad reflections in the learned poet's mind.

The Lazarus Poems, by Kamau Brathwaite (Middletown CT: Wesleyan University Press, 2017, cloth US \$24.95), follows quickly on the heels of Strange Fruit and Leviticus and confronts death and the afterlife head-on. For us, it's his most powerful work in a long time-moving, gripping, a flow of Caribbean ideas and allusions that in a sense sums up much of his life's work. This book is a rare gift, a wondrous read.

We very much liked Beneath the Spanish (Minneapolis MN: Coffee House, 2017, paper US\$16.95), by Puerto Rico-born Victor Hernández Cruz, who lived for years in New York but for some time now has resided in Morocco. Several pages in poetic prose begin each chapter-"Primer Encuentro entre Dos Mundos," "Childhood in the Latin Caribbean," "Lower East Side Red Brick Blues," "Chocolate," "Borges y Nabokov," "Latin Boogaloo," "Reading Japanese in Morocco," and so on-which are then followed by poetry on the same theme, both improvised "within Latin Jazz." History, literature, and autobiography, seen through a special lens, at once anticolonial, accepting of relative powerlessness, and delighting in the wonders of the world.

Miami Century Fox, by Legna Rodríguez Iglesias (Brooklyn NY: Akashic, 2017, paper US\$15.95), winner of the Paz Prize for Poetry, presents facing-page bilingual (Spanish/English) sonnets translated by Eduardo Aparicio-direct and contemporary in tone and feeling, reflecting on matters of daily life and the state of the soul in exile. We liked these poems!

¡Manteca! An Anthology of Afro Latin@ Poets (Houston TX: Arte Publico, 2017, paper US\$21.95), edited with an excellent introduction by Mexican-American writer Melissa Castillo-Garsow, presents more than 40 mostly-Caribbean poets active during the past half-century (with three to ten poems from each). A fine collection, highlighting racism both in the United States and at home in Puerto Rico, the Dominican Republic, and elsewhere in the region.

In Sin lengua, deslenguado (Madrid: Catedra, 2017, paper US\$19.10), Yannelys Aparicio \& Ángel Esteban introduce and present numerous excerpts from the published work of Gustavo Pérez Firmat, who famously wrote that he was "nacido en Cuba, made in the USA." Cutting, funny, exhilarating.

Finally, three books of Caribbean theater.

The first publication of two 193 os plays by Jamaican poet, editor, journalist, and dramatist Una Marson, Pocomania and London Calling (Kingston: Blouse \& Skirt Books, 2016, paper US\$20.99), is an important moment in the history of Caribbean theater. While the comedic London Calling is about black stu- 
dents from the British Empire and their experiences in the capital, Pocomania, first staged in Kingston in 1938, concerns class, culture, gender, language, and color in the waning days of the colony. Both add to the legacy of this pioneer Jamaican feminist.

Les Veuves créoles, comédie (Cambridge: Modern Humanities Research Association, 2017, paper £10.99) is the earliest-known play to have been written in Martinique (and the first published literary work from that colony), published anonymously, allegedly in Amsterdam but more likely in Paris, in 1768 . Julia Prest, who has edited and introduced the text here, writes an extensive, scholarly contextualization not only of this play and its central themes but of eighteenth-century theater in the French Caribbean colonies more generally. A model presentation of an important text.

The 3oth book by First Nation author Drew Hayden Taylor, Crees in the Caribbean (Vancouver, Canada: Talonbooks, 2017, paper US\$18.95), is a comedic three-person play about a middle-aged Cree couple from Saskatchewan who had never traveled celebrating their $35^{\text {th }}$ wedding anniversary on Mexico's Caribbean coast. Multicultural mayhem ensues.

Some diverse nonfiction not otherwise reviewed in NWIG:

In Conversations with Edwidge Danticat (Jackson: University of Mississippi Press, 2017, cloth US\$6o.oo), editor Maxine Lavon Montgomery presents 22 previously published, relatively brief interviews (from newspapers, journals, radio ...) made between 2000 and 2016, plus a new one she recently conducted and a useful chronology of Danticat's life and works. Subjects range widely, from Danticat's childhood in Haiti, her coming to Brooklyn to join her family at the age of twelve, and her stunning literary career. Haiti-its history, culture, suffering, and ebullient resistance-always remains at the core.

The BlackJacobins Reader, edited by Charles Forsdick \& Christian Høgsbjerg (Durham NC: Duke University Press, 2017, paper US\$28.95), presents a wealth of contributions - from revolutionary U.S. prisoners Mumia Abu-Jamal and Russell Maroon Shoatz as well as major scholars such as Laurent Dubois, Carolyn Fick, and David Scott, among many others. As George Lamming says in his blurb, "This is the most authoritative confirmation to date of the intellectual stature of C.L.R. James and the prophetic grandeur of his great classic."

Haiti: The Perpetual Liberation (Zurich, Switzerland: Scheidegger \& Spiess, 2017 , paper US\$39.0o) is a cardboard-boxed set of four small-format paperbacks: the first contains Thomas Kern's black-and-white photos of Haiti taken over a twenty-year-long period; the second an English-language collection of brief essays by Kerns, Haitian novelist Yanick Lahens, and others, edited by Nadine Olonetzky, about Haiti; and the third and fourth are versions in German and Haitian Creole, respectively, of the English texts. Prepared to accompany a 
Swiss exhibition of the photos, the publication remains a curiosity, the images small and in the end routine, well-meaning (like the essays) but unsurprising.

Found in an envelope in renowned Cuban writer Guillermo Cabrera Infante's house after his death in 2005, Map Drawn by a Spy was finally approved by his widow for publication in Spain in 2013 and has now appeared in an English translation by Mark Fried (Brooklyn NY: Archipelago, 2017, paper US $\$ 18.00$ ). Written in the third person, this is nevertheless an autobiography (almost a diary) of his return to Havana in 1965 for his mother's funeral, staying (being delayed by the bureaucracy) for four months, after he'd spent three years as cultural attaché in Brussels. It is at once gripping, politically fascinating, filled with erotic encounters, and supremely melancholic, with the author constantly comparing pre-and post-Revolutionary life as well as the increasing sclerosis of the society during the previous three years-the persecution of homosexuals and other counter-revolutionaries, the shortage and rationing of food, the dilapidation of the cityscape. In his daily meetings with old friends (writers, musicians, and people in the arts and cinema, from Alejo Carpentier, José Lezama Lima, and Nicolás Guillén to Edmundo Desnoes and Tomás Gutiérrez Alea), we are treated to the thoughts of an intellectual who had become a stranger in his own country and who, right after the events in this book, left Cuba never to return.

Sugar: The World Corrupted, from Slavery to Obesity, by James Walvin (London: Robinson, 2017, cloth £18.99), is a chatty, less didactic knock-off of Sidney Mintz's 1985 Sweetness and Power, focusing more than that pioneering work on the health dangers of sugar consumption. There's little new here for Caribbeanists. The text quotes Mintz only once but, as Walvin admits in his acknowledgments, although his book "is not intended as a successor to [Mintz's] ... it certainly could not have been written without it."

Published with much media hype, So Much Things to Say: The Oral History of Bob Marley, by Roger Steffens (New York: Norton, 2017, cloth US\$29.95), is aimed at reggae enthusiasts who can't get enough about the great man. Based on 74 interviews (presented pretty much verbatim) recorded over several decades with family, friends, and bandmates, the book moves chronologically from Marley's humble beginnings through his years of triumph to his final days. As the Jamaican saying has it, "there are no facts, only versions." For devotees, this book contains a multitude.

Papillote Press has published In the Forests of Freedom: The Fighting Maroons of Dominica (London, U.K. and Trafalgar, Dominica, 2017, paper, US\$13.46) by Lennox Honychurch. An earlier version, which Honychurch self-published in 2014, was reviewed in "Bookshelf 2015." Of the current revised and improved publication, RP wrote for its back flap: "Detailed and eminently readable, it will 
long stand as the definitive account of these Maroons whom the British considered, after those in Jamaica, the major menace to their plantation system. Dominica's Maroons have finally found their chronicler."

Jamaica, the Land of Film, by Peter Polack (Cambridge: Cambridge Scholars Publishing, 2017, cloth £61.99), chronicles more than a century of film-making in Jamaica, covering well over 100 films. Somewhere between a history and a gossip column in style, with many illustrations of movie stars and local settings, the book moves chronologically from A Daughter of the Gods, a 1916 one million-dollar silent extravaganza, through Knight and Day, starring Tom Cruise (2010). Within these pages, there's something to amuse almost everyone.

Animal Tales from the Caribbean, collected by George List, edited by John Holmes McDowell \& Juan Sebastián Rojas E. (Bloomington: Indiana University Press, 2017, paper US $\$ 50.00$ ), presents 21 folktales (in English translation and the original Spanish) recorded by List during funeral wakes on the Colombian Caribbean coast during 1964-65. The edition is scholarly and the tales a joy.

Earl Lovelace, by Funso Aiyejina (Kingston: University of the West Indies Press, 2017, cloth US\$24.12), is part of the Caribbean Biography Series, intended to "celebrate ... the architects of Caribbean culture" and "introduce general readers" to them. Drawing on Lovelace's personal papers and his still-unfinished autobiography, Aiyejina-longtime Lovelace scholar-completes the 10o-page job with aplomb.

In Frantz Fanon: Traces d'une vie exemplaire (Paris: L'Harmattan, 2016, $€$ 9.0o), Martiniquan and Algerian militant Daniel Boukman offers a straightforward, very brief yet moving account of Fanon's life, drawn largely from secondary sources, followed by a three-page letter Boukman wrote in Rabat upon Fanon's death in Washington in December 1961, as he waited to join the FLN. It expresses, in Fanonian cadences, his own (and three comrades') reasons for committing the crime of insubordination-refusing to don the uniform of the French army. (Boukman remained in independent Algeria, teaching in a lycée, from 1962 until 1981, when - having already received amnesty from France-he returned to Paris and in 1999 to Martinique. In addition to journalistic work, he has continued to produce numerous books of poetry, theater, and prose, much of it in Creole.)

Devoir marronner aujourd'hui dans l'espace des Guyanes, by Joël Roy (Paris: L'Harmattan, 2017, paper $€ 15.50$ ), is an incoherent 141-page text, claiming to treat Roman slavery, the Islamic slave trade, the transatlantic trade (without in any way examining the origins of slaves shipped to the Guianas!), marronage in the Americas, Maroon religion, and a number of related topics, each in severalpage segments. L'Harmattan should be ashamed of publishing such a workwe said much the same about a previous book by Roy in "Bookshelf 2015." 
In the coffee-table sized Campesinos: Inside the Soul of Cuba (Tuscaloosa: University of Alabama Press, 2017, cloth US\$49.95), Alabama-born Chip Cooper \& Cuban Julio Larramendi present the striking photographic fruits of their travels through Cuba's interior, depicting landscapes, homes, and people at work and at play, all in color and with caption information limited to place and photographer. It joins a long tradition of such photo albums reviewed in these pages, hard to distinguish one from another.

Havana without Makeup: Inside the Soul of the City (Brooklyn NY: Turtle Point Press, paper US\$18.95) is a "rambling walkabout" of the city, presented in 87 brief chapters by Herman Portocarero, long-time Belgian and EU ambassador to Cuba. History, architecture, culture, and politics combine in this personal, warm, knowledgeable homage.

Conflict and Sustainability in a Changing Environment: Through the Eyes of Communities, by Gwendolyn Smith \& Elena P. Bastidas (London: Anthem Press, 2017, cloth US $\$ 115.00)$, makes an argument for sustainable development using the case of the Trio Indians of Suriname. It deals with climate change, the UN's REDD+ project, and similar initiatives, and will be of interest mainly to policy analysts.

We note the recent publication of two Dutch dissertations on Virgin Islands Dutch Creole (Negerhollands), the language spoken by eighteenth-century enslaved Africans and their descendants in the Danish West Indies and described mainly by Moravian missionaries: The Virgin Islands Dutch Creole Textual Heritage: Philological Perspectives on Authenticity and Audience Design, by Cefas van Rossem (Utrecht: LOT, 2017, € 41.00), and Variation and Change in Virgin Islands Dutch Creole: Tense, Modality and Aspect, by Robbert van

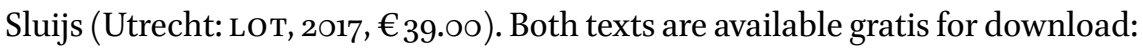
https://www.lotpublications.nl/the-virgin-islands-dutch-creole-textualheritage-philological-perspectives-on-authenticity-and-audience-design and https://www.lotpublications.nl/variation-and-change-in-virgin-islands-dutchcreole.

Anyone tempted to doubt the current vibrancy and eclecticness of artistic creativity throughout the Caribbean should spend some time with Relational Undercurrents: Contemporary Art of the Caribbean Archipelago (Long Beach CA: Museum of Latin American Art, paper US $\$ 50.00$, distributed by Duke University Press). Over 300 pages of interesting, authoritative essays and stunning images confirm the argument made by editors Tatania Flores \& Michelle A. Stephens in their introduction that the trope of Caribbean heterogeneity and fragmentation is ripe for replacement by an archipelagic model. Compared to the equally hefty omnibus volume on Caribbean art put out by the Museo del Barrio five years ago (reviewed in NWIG 88-3\&4), the focus is on twenty- 
first-century art and the media in question are more insistently wide ranging, from photography, film, installations, and performance art through painting, sculpture, mixed media (from plexiglass to fish hooks), posters, murals, and more.

Les processus de reconfiguration dans l'art caribéen (Paris: L'Harmattan, 2017, paper $€ 27.5$ ) , a revised doctoral thesis by José Lewest, compares "aesthetic strategies" in three Caribbean settings of contrastive cultural, linguistic, and political history - Guadeloupe, Haiti, and Jamaica - from the eighteenth century to the present day. It builds on insights by a wide range of art historians such as David Boxer, Veerle Poupeye, and Richard Powell as well as social and cultural commentators, from Roger Bastide, Frantz Fanon, and Édouard Glissant to "William E.B. Dubois," Paul Gilroy, Stuart Hall, and Achille Mbembe. It has no illustrations.

Saveurs de Guyane, edited by Didier Béreau (Paris: Le Livre d'Art, 2017, cloth $€$ 45.00), complements its recipes with stunning photographs of raw ingredients (many of the various fish, animals, fruits, and vegetables of the region) and finished dishes, as well as farmers, cooks, and others in the food business, and a multitude of local scenes. Weighing in at five pounds, it devotes many of its super-sized pages to background information about Guyane, from the history of markets and shrimp fishing to the economics of agriculture. The numerous authors (of both recipes and essays) provide interesting details on Guyane and its foods. To cite just two, ethnobotanist Marie Fleury's excellent piece on Maroons' production and use of maripa oil is concisely informative. On the other hand, Aluku Maroon Tomou Dinguiou, self-styled "Professor of Busikonde tongo," writes a piece on "Cuisine Bushinengue" portraying manioc as the staple food, never mentioning that the staple of Saamakas has always been rice. Only three "cuisines" are recognized in the book: "Creole," "Bushinengue" (without further distinction), and "Amerindian" — nothing on the Hmong, who provide the bulk of fresh vegetables in the territory (and nothing on Haitians or Brazilians). We haven't yet put the recipes to the test.

A second edition has been published of Dale W. Tomich's important (1990) Slavery in the Circuit of Sugar: Martinique and the World-Economy, 1830-1848, (Albany: State University of New York Press, 2016, paper US\$29.95), including a new introduction by the author.

Richard and Sally Price have published a new French edition of Enigma Variations (Harvard University Press, 1995), their illustrated novel about art forgery in Guyane. Boléro Tropical (CreateSpace, 2018, paper, US\$14.95) is now available on amazon.com and amazon.fr.

We somehow missed Rupert Roopnaraine's The Sky's Wild Noise: Selected Essays (Leeds, U.K.: Peepal Tree Press, 2013, paper US\$48.95) when it was pub- 
lished, but Jay R. Mandle has sent a brief evaluation: "This collection of previously published articles, speeches, and reviews by Guyana's current Minister of Education is particularly valuable because of the insight it provides about the Working People's Alliance's opposition to Forbes Burnham and its ambivalent attitude toward the Grenada Revolution. Beyond that, it reveals Roopnaraine's deeply felt appreciation of literature and the arts."

Once again, Rosemarijn Hoefte has provided an excellent overview of recent Dutch-language books that may be of interest to our readers:

Good news and bad news about publishing on the Caribbean in the Netherlands. Starting with the bad: Oso, tijdschrift voor Surinamistiek en het Caraïbisch gebied, which was the most prominent outlet for articles on the Caribbean in Dutch, has folded after 35 volumes. Far more positive is the number of nicely produced books that LM Publishers (in Volendam, the Netherlands) is putting on the market. About two thirds of the volumes discussed here are by this publisher, which specializes in Indonesia, Suriname, and the 'Dutch' Caribbean islands.

Four volumes on Curaçaoan history. Kas di shon: Plantagehuizen op Curaçao, vroeger en $n u$ (LM Publishers, 2017, paper € 24.50), edited by Sandra van Noord, is a beautifully illustrated guide to 18 mansions on the island. The book is published in anticipation of Curaçao's nomination of several plantations and their buildings for UNESCo's World Heritage List. Despite its weight, it's highly recommended for visitors. De Willemstad: Het dagelijks leven in negentiendeeeuws Punda (LM Publishers, 2017, cloth $€_{17.50}$ ) is based on a manuscript by the late Els Langenfeld and written by journalist Jeannette van Ditzhuijzen. This richly illustrated social history of nineteenth-century Punda, a neighborhood of Curacao's capital Willemstad, discusses street life and transportation, commerce, population, schools, colors and smells, and much more. Geest van Sefarad: Een joodse odyssee, by Fred de Haas (Amsterdam: Caribpublishing, 2017, paper $€ 19.90$ ), succinctly discusses the Sephardi diaspora in general and the history and culture of this group in Curaçao in particular. A classic with a new look is Sambumbu: Volkskunde van Curaçao, Aruba en Bonaire by Paul Brenneker (Amsterdam: Caribpublishing, 2017, 4 vols, paper $€ 22$ each). Brenneker (1912-96), a Dominican friar, and Elis Juliana (1927-2013) collected information from a great diversity of sources on the history and culture of the three islands that was randomly published in ten volumes between 1969 and 1975 . These new volumes are now thematically arranged: language; religion and rituals; people and customs; songs and music.

More on the islands: Peter Verton's Burgers \& broeders: Goed bestuur en natievorming in Curaçao (LM Publishers, 2017, cloth €24.50) discusses (the history of) emancipation, nation building, and good governance but lacks 
the analytical power to convince. Artwell Cain's A Sense of Belonging ... (LM Publishers, 2017, paper $€ 19.50$ ) is an attractive collection of 39 stories and portraits of English-speaking Arubans from San Nicolas focusing on migration, identification with Aruba, and representation. Enith Brigitha: Zwemmen in de schaduw van doping, by Jeannette van Ditzhuijzen (LM Publishers, 2017, paper $€$ 19.5०), is an overly detailed biography of Curaçaoan-Dutch swimmer Brigitha, the first Olympic medal winner of African descent (Montreal 1976). As the subtitle indicates however, most of the book deals with what could have been, if the competing GDR swimmers hadn't been forced to use doping.

Ralph Mohren's De hemel is zwart vandaag (Amsterdam: Meulenhoff, 2017, paper $€ 18.99)$ is a bleak but fascinating novel situated in Curaçao in the late 1990s. The Dutch protagonist, often drenched in alcohol or lost in Campo Alegre, writes letters to the late author Tip Marugg in attempts to find his mental balance. Ver weg dichtbij is a collection of radio columns by Boeli van Leeuwen (1922-2007), edited by Jos B. de Roo (Haarlem, the Netherlands: In de Knipscheer, 2017, cloth $€_{17.90}$ ). These 29 columns, aired between December 1951 and July 1954 by the Wereldomroep, still sparkle and are the first literary expressions by one of the "great Curaçaoan three" (Marugg, Frank Martinus Arion, and Van Leeuwen). A joy to read! Finally on the islands a booklet, No ta abo so/Jij bent niet de enige (LM Publishers, 2017, cloth €10.00), containing 16 poems in Papiamentu and Dutch by Jorge G.R. Labadie Solano with drawings by José M. Capricorne.

Over to Suriname: Ellen de Vries's 2015 dissertation on media attention for Suriname has been published as Mediastrijd om Suriname: Van mythemakers tot nieuwsverduisteraars (Zutphen, the Netherlands: Walburg Pers, 2017, paper $€ 29.95)$. In six case studies she describes and analyzes Dutch and Surinamese press coverage of Suriname in the period $198 \mathrm{o}-92$. Of course, one of the protagonists is Desi Bouterse, the revolutionary military leader turned elected president. Yet De Vries's reconstruction shows that during this period the Dutch press wasn't as obsessed with the man as is often proclaimed. The reconstruction of the cases is interesting, especially in light of current developments regarding the prosecution of human rights violations committed in the 1980 s. De Vries's conclusions about framing are highly relevant, but not surprising. Much less thorough, Sylvana van den Braak's A friwortu, the Free Word:Censorship in Surinam (Amsterdam: Eva van der Tas Foundation, 2017, paper, free of charge) takes the discussion to the present day. Her booklet, largely based on a dozen interviews with journalists in Suriname, identifies a number of issues limiting freedom of the press: undue influence by politicians and business interests, low salaries, self-censorship in a small society, and poor education and training. 
Onbeschreven erfgoed: Perspectieven op de Surinaams-Hindostaanse cultuur, edited by Ruben Gowricharn (LM Publishers, 2017, paper $€ 17.5^{\circ}$ ), is a rather predictable collection of nine articles on Hindustani or East Indian culture in Suriname intended for a general public. Topics discussed include architecture, cuisine, dance, dress, film, jewelry, music and musical instruments, and poetry. Ram Hiralal: De kaarten op tafel (LM Publishers 2017, paper $€_{19.50}$ ) is a biography of a Surinamese accountant penned by Roy Khemradj. The commercial side of the story is rather dull, but the book gives some interesting insights into postwar Hindustani economic, cultural, and social networks.

A must-have for anybody interested in Suriname is Commewijne: Plantages, Javanen en andere verhalen, by Fineke van der Veen \& Dick ter Steege (LM Publishers, 2016, cloth $€ 24.5^{\circ}$ ), on the traditional plantation district that is now rapidly changing on account of the bridge connecting it to Paramaribo. The first part discusses the (mostly Javanese) inhabitants, while the second focuses on the history and architecture of the district's built cultural heritage. Another jewel is Zinkplaat en planken: Het verdwijnen van de houten volkswoning in Paramaribo, by Wim Verboven (LM Publishers, 2016, cloth € 24.50), a pictorial presentation of 100, often dilapidated, wooden houses in Suriname's capital. Bomen van Paramaribo: Een ode aan de mooiste hoofdstad in de tropen (LM Publishers, 2017, paper €19.50), by Dominiek Plouvier \& Chantal Van den Bergh-Lodeweyckx, is a two-part, educational introduction to 100 trees in Paramaribo. The richly illustrated first part gives local and Latin names, and provides botanical, geographical, cultural-historical, and medical details. The second part consists of six walks through Paramaribo. A nice town, but the most beautiful capital in the tropics?

De Dageraad: Waar het verhaal van Sonny Boy begon (Amsterdam: Querido, 2017, cloth $\left.€_{15} .00\right)$, by Dutch author Annejet van der Zijl, is a fairly shameless attempt by her publisher to make even more money off Van der Zijl's bestseller Sonny Boy (2004), the true story of the Surinamese-Dutch couple Waldemar Notts and Rika van der Lans. It describes the everyday racism of the 1930s. In 1944 they were betrayed after hiding Jews, and both died in captivity. De Dageraad is a thin history of the plantation where ancestors of Waldemar Notts lived and worked. Anansi 2.o: Tien nieuwe verhalen (LM Publishers, 2017, cloth €9.5०) is a project of the writers' workshop (schrijversvakschool) in Paramaribo. The tales were edited by Paul Middellijn without consultation of the authors. The quality of the stories is uneven; the most innovative is the female Javanese incarnation of the spider as Mbok Anansi by Rita Tjien Fooh.

Voudou: Van New Orleans naar Cotonou op het ritme van de goden, by music journalist Leendert van der Valk (Amsterdam: Atlas Contact, 2017, paper 
$€$ 24.99), is a fast-paced account that takes us from the U.S. South to Haiti, Curaçao, Suriname, Benin, and Togo. The author is an enthusiastic participant while maintaining a matter-of-fact style. Finally, Nanne Timmer compiled 12 stories by Cuban authors born between 1970 and 1988 in La Isla de Cuba: Twaalf verhalen \& één revolutie (Baarn, the Netherlands: Marmer, 2017, paper $€ 17.95$ ). This anthology includes contributions by Ena Lucia Portela, Waldo Pérez Cino, and Ronaldo Menéndez. A pleasure to read even though in some stories the connection to the Cuban Revolution or the State is tenuous at best.

We end this year's Bookshelf by listing information on titles that we have noticed but neither examined nor requested for review-in some cases because their Caribbean content is restricted to a chapter or two, in others because they didn't seem sufficiently compelling given NWIG space limitations, or for a variety of other reasons. Together, they testify to the large number of books being published that at least touch on the Caribbean.

L'humanité des Noirs: L'apport de la Négritude aux droits de l'Homme, by Clément Claude Trobo \& Colette Maximin (Paris: L'Harmattan, 2017, paper € 45.00)

Le marronnage dans la littérature caribéenne, by Alexandre Roch (Paris: L' Harmattan, 2017, paper $€$ 34.00)

Sous la dictée de Fanon, by Marie-Jeanne Manuellan (Coaraze, France: L'Amourier, 2017, paper $€ 17.00)$

Un monde créole - Vivre aux Antilles au XVIIIe siècle, edited by Annick Notter \& Erick Noël (La Crèche, France: Geste Éditions, 2017, paper € 29.00) [Martinique, Guadeloupe, Saint-Domingue]

Our Woman in Havana: A U.S. Diplomat's Chronicle of America's Long Struggle with Castro's Cuba, by Vicki Huddleston (New York: Overlook Press, 2018, cloth US\$29.95) Havana Living Today: Cuban Home Style Now, by Hermes Mallea (New York: Rizzoli, 2017, cloth US\$55.00)

Hemingway's Havana: A Reflection of the Writer's Life in Cuba, by Robert Wheeler (New York: Skyhorse, 2018, cloth US\$24.99)

Ernesto: The Untold Story of Hemingway in Revolutionary Cuba, by Andrew Feldman (Brooklyn NY: Melville House, 2017, cloth US\$27.99)

300 Reasons to Love Havana, by Heidi Hollinger (New York: Juniper, 2018, paper US\$19.95)

Cuba Loves Baseball: A Photographic Journey, by Ira Block \& Bob Costas (New York: Skyhorse, 2018, cloth US\$27.99)

Cuba Then: Revised and Expanded, by Richard Blanco (New York: Monacelli Press, 2018, cloth US\$40.00)

Cuba: 101 Beautiful and Nostalgic Places to Visit, by Michael Connors (New York: Rizzoli, 2017, cloth US\$50.00.) 
Cuba Stone, by Javier Siney, Joselo \& Jeremías Gamboa (Barcelona, Spain: Tusquets, 2016, Kindle $€$ 14.24)

Cuba Arts, by Charles Fields (Truro MA: Fields Publishing, 2017, cloth US\$24.99) [photos]

Cuba Cars: Classics of the Caribbean (English and German Edition), by Rainer Floer \& Harri Morick (Bielefeld, Germany: Delius Klasing Verlag, 2017, cloth US\$40.00)

Readers and Writers in Cuba: A Social History of Print Culture, 1830s-199os, by Pamela Maria Smorkaloff (London: Routledge, 2017). [Paperback edition of book published in 1997]

Cuba and Angola: the War for Freedom, by Harry Villegas (Atlanta GA: Pathfinder, 2017, paper US\$10.00)

The United States and Cuba: From Closest Enemies to Distant Friends, by Francisco López

Segrera (Lanham MD: Rowman \& Littlefield, 2017, paper US\$25.00)

De la Habana a la paz, by William Ospina (New York: Debate, paper US\$18.95)

Escravidão e capitalismo histórico no século XIX: Cuba, Brasil e Estados Unidos, edited by Rafael Marquese \& Ricardo Salles (Rio de Janeiro: Civilização Brasileira, 2016, paper $\mathrm{R} \$ 49.90)$

The Guyana Contract, by Rosalind Kilkenny McLymont (New York:The Network Journal Communications, 2015, paper US\$19.95) [a thriller]

Puerto Rico (On the Road Histories), by John H. Chambers (Northampton MA: Interlink, 2018, paper US\$25.00)

Clemente, en la víspera de la gloria, by Néstor Duprey Salgado (San Juan: 2017, paper US\$45.00)

En la azotea: 10 piezas cortas de teatro, by Alejandra Ramos Riera (San Juan: Ediciones Callejón, 2017, paper US\$14.95)

Coming of Age in Wonderland: Portraits of Teenage Bermuda, by photographer Debra Friedman (s.l.: Daylight Books, 2018, cloth US\$ 45.00)

By Fire and Bayonet: Grey's West Indies Campaign of 1794, by Steve Brown (Solihull, U.K.: Helion, 2018, cloth US\$49.95)

From the Krays to Drug Busts in the Caribbean, by Ian Brown (Barnsley, U.K.: Pen and Sword, 2018, paper US\$24.95)

Drug Trafficking, Organized Crime, and Violence in the Americas Today, edited by Bruce M. Bagley \& Jonathan D. Rosen (Gainesville: University of Florida Press, 2015, paper US\$35.00)

Caribbean Realities and Endogenous Sustainability, edited by Debbie A. Mohammed \& Nikolaos Karagiannis (Kingston: University of the West Indies Press, 2018, paper US\$65.00)

An Archaeological Study of the Red House, Port of Spain, Trinidad and Tobago, edited by Basil A. Reid (Kingston: University of the West Indies Press, 2018, paper US\$40.0o) Distant Voices Near: Historical Globalization and Indian Radio in Trinidad and Tobago, 
by Shaheed Nick Mohammed (Kingston: University of the West Indies Press, 2017, paper US\$35.00)

What Do Jamaican Children Speak? A Language Resource, by Michele M. Kennedy (Kingston: University of the West Indies Press, 2017, paper US\$40.0o)

Reggae Stories: Jamaican Musical Legends and Cultural Legacies, edited by Donna

P. Hope (Kingston: University of the West Indies Press, 2018, paper US\$45.0o)

Reggae Larger Than Life:The Ultimate Reggae Music Fun and Games, by Shaun Cain (s.l.: CreateSpace, 2017, paper US\$28.50)

Jamaica Insider, by Charles Fields (Truro MA: Fields Publishing, 2017, cloth US\$24.99) [photos]

White Liver Gal, by Diana McCaulay (s.l.: Kindle, Amazon Digital Services, US\$2.99) [self-published novel about Jamaica]

Violence in Latin America and the Caribbean: Subnational Structures, Institutions, and Clientelistic Networks, edited by Tina Hilgers \& Laura Macdonald (Cambridge: Cambridge University Press, 2017, cloth $£_{75}$.00) [only one chapter on the CaribbeanJamaica]

The Influence of Small States on Superpowers: Jamaica and US Foreign Policy, by Richard

L. Bernal (Kingston: University of the West Indies Press, 2018, paper US\$45.00)

Mediatized Political Campaigns: A Caribbean Perspective, by Indrani Bachan-Persad

(Kingston: University of the West Indies Press, 2017, paper US\$35.00)

Still on Air: Producing Television in Small Markets, by Yvette J. Rowe \& Livingston A. White (Kingston: University of the West Indies Press, 2018, paper US\$35.0o) [re: Jamaica]

Language Variation on Jamaican Radio, by Michael Westphal (Amsterdam: John Benjamins, 2017, cloth US\$105.00)

The Grooming of a Chancellor, by George Alleyne (Kingston: University of the West Indies Press, 2018, paper US\$50.00)

The African-Jamaican Aesthetic: Cultural Retention and Transformation across Borders, by Lisa Tomlinson (Leiden, the Netherlands: Brill, 2017, cloth US\$112.00)

Belly Full: Caribbean Food in the U.K., by Riaz Phillips (London:Tezeta Press, 2016, cloth $£ 23.00$ )

Dub Poets in their Own Words, by Eric Doumerc (s.l.: CreateSpace, 2017, paper US\$8.99) Small Countries: Structures and Sensibilities, edited by Ulf Hannerz \& Andre Gingrich (Philadelphia: University of Pennsylvania Press, 2017, cloth US\$65.00) [two chapters (out of 16) on Belize and Jamaica]

Global Change and the Caribbean: Adaptation and Resilience, edited by David Barker,

Duncan McGregor, Kevon Rhiney \& Thera Edwards (Kingston: University of the West Indies Press, 2016, paper US\$40.0o)

Jah Kingdom: Rastafarians, Tanzania, and Pan-Africanism in the Age of Decolonization, by Monique A. Bedasse (Chapel Hill: University of North Carolina Press, 2017, paper US\$32.95) 
The West Indian Generation: Remaking British Culture in London, 1945-1965, by Amanda

Bidnall (Liverpool U.K.: Liverpool University Press, 2017, cloth US\$114.07)

Archaeological Perspectives on the French in the New World, edited by Elizabeth M. Scott

(Gainesville: University of Florida Press, 2017, cloth US\$ 89.95) [3 of 10 chapters deal with St. Croix, Guadeloupe-Martinique, and Guyane]

The Gift of Rose, by Adair Arlen (s.l.: CreateSpace, 2017, paper US\$11.99) [self-published novel about Montserrat]

Mr. Rochester: A Novel, by Sarah Shoemaker (New York: Grand Central Publishing, 2017, cloth US\$27.00)

The Island That Disappeared: Old Providence and the Making of the Western World, by Tom Feiling (London: Turnaround Publishing Services-Explore Books, 2017, paper US\$12.23)

Faulkner and the Black Literatures of the Americas, edited by Jay Watson \& James G. Thomas, Jr. (Jackson: University of Mississippi Press, 2016, cloth US\$65.00)

Vampires and Zombies: Transcultural Migrations and Transnational Interpretations, edited by Dorothea Fischer-Hornung \& Monika Mueller (Jackson: University of Mississippi Press, 2016, cloth US\$65.00)

Music Education in the Caribbean and Latin America: A Comprehensive Guide, by Raymond Torres-Santos (Lanham MD: Rowman \& Littlefield, 2017, paper US\$45.0o)

Steelpan Ambassadors: The US Navy Steel Band, 1957-1999, by Andrew R. Martin (Jackson: University of Mississippi Press, 2017, cloth US\$65.0o)

The Caribbean Court of Justice: Regional Integration Court in a Global Context, by Jan Yves Remy (London: Routledge, 2017, cloth US\$150.00)

Rum Curious: The Indispensable Guide to Tasting the World's Spirit, by Fred Minnick (Minneapolis MN: Voyageur Press, 2017, cloth US\$25.00)

Creative Practice and Socioeconomic Crisis in the Caribbean: A Path to Sustainable Growth, by Kent J. Wessinger (London: Routledge, 2017, cloth US\$135.00)

Economic and Social Impacts of Food Self-Reliance in the Caribbean, by Ekaterina Dorodnykh (Basingstoke, U.K.: Palgrave Macmillan, 2017, cloth US\$54.99)

Women Writing Resistance: Essays on Latin America and the Caribbean, edited by Jennifer Browdy (Boston: Beacon Press, 2017, paper US\$13.98) [originally published in 2003 by South End Books, which went out of business; now republished by Beacon]

Border Crossing Brothas: Black Males Navigating Race, Place, and Complex Space, by Ty-Ron M.O. Douglas (New York: Peter Lang, 2016, paper US\$42.95) [on the United States and Bermuda]

Indian and Slave Royalists in the Age of Revolution: Reform, Revolution, and Royalism in the Northern Andes, 1780-1825, by Marcela Echeverri (Cambridge: Cambridge University Press, 2017, cloth US\$99.99) [some relevance to Atlantic studies]

Orality, Identity, and Resistance in Palenque (Colombia): An Interdisciplinary Approach, 
edited by Armin Schwegler, Bryan Kirschen \& Graciela Maglia (Amsterdam: John Benjamins, 2017, cloth US\$105.00) [updated translation of the 2012 Spanish-language publication]

Language Contact in Africa and the African Diaspora in the Americas: In Honor of John V. Singler, edited by Cecilia Cutler, Zvjezdana Vrzić \& Philipp Angermeyer (Amsterdam: John Benjamins, 2017, cloth US\$105.00) 